\title{
Serotonergic and Cholinergic Systems Dysfunction in Autism Spectrum Disorders
}

\author{
Behzad Saberi* \\ Medical Research, Esfahan, Iran \\ Submission: November 26, 2020; Published: January 07, 2021 \\ *Corresponding author: Behzad Saberi, Medical Research, Esfahan, Iran
}

Keyword: Autism; Brain's function; Patients; Serotonin; Neurotransmitters

\section{Mini Review}

Serotonin is synthesized from tryptophan which is an essential amino acid. Tryptophan hydroxylase will hydroxylate tryptophan into 5-hydroxytryptophan and then aromatic L-amino acid decarboxylase will decarboxylate it into 5-hydroxytryptamine or serotonin. Adult brain's function and plasticity would be modulated by serotonin. Also developing brain's target regions maturation and serotonergic outgrowth regulation would be done by serotonin. Based on positron emission tomography studies, in the patients with autism, 5-hydroxytryptamine synthesis related normal brain developmental peak cannot be seen. In about one-third of the autism cases, the whole blood serotonin levels are elevated which can result in abnormalities in the cellular immunity. Also, in the patients with autism, platelets, whole blood and cortical 5-HT2 receptors binding may be decreased. In the patients with autism, the serotonin levels regulation may be done by ITGB3 gene. Also, serotonin transporter gene SLC6A4 promoter region's polymorphisms can have association with autism.

Choline acetyltransferase action results in acetylcholine synthesis from choline and acetyl-CoA. Muscarinic and nicotinic receptors are two kinds of acetylcholine receptors. Basal forebrain cholinergic neurons deficits can result in cognitive deficits like learning and attention problems in the patients with autism [1-7].

There are various dysfunctions in some neurotransmitters and their relations with the receptors in the autism spectrum disorders which trying to understand such neuropathological deficits could result in finding novel treatment options for the patients with autism.

\section{References}

1. Quaak I, Brouns MR, Van de Bor M (2013) The dynamics of autism spectrum disorders: How neurotoxic compounds and neurotransmitters interact. Int J Environ Res Public Health 10(8): 3384-3408.

2. Muller CL, Anacker AM, Veenstra-Vander Weele J (2016) The serotonin system in autism spectrum disorder: From biomarker to animal models. Neuroscience 321: 24-41.

3. West L, Brunssen SH, Waldrop J (2009) Review of the evidence for treatment of children with autism with selective serotonin reuptake inhibitors. J. Spec. Pediatric Nurs 14(3): 183-191.

4. Gabriele S, Sacco R, Persico AM (2014) Blood serotonin levels in autism spectrum disorder: A systematic review and meta-analysis. Eur. Neuropsychopharmacol 24: 919-929.

5. Yang CJ, Tan HP, Du YJ (2014) The developmental disruptions of serotonin signaling may involved in autism during early brain development. Neuroscience 267: 1-10.

6. Deutsch SI, Burket JA, Urbano MR, Benson AD (2015) The $\alpha 7$ nicotinic acetylcholine receptor: A mediator of pathogenesis and therapeutic target in autism spectrum disorders and Down syndrome. Biochem. Pharmacol 97(4): 363-377.

7. AryaA,Sindhwani G (2016) Autism: An early-onsetneurodevelopmental disorder. Int J Pharm Sci Res 7: 3567. 
(C) This work is licensed under Creative CC) Commons Attribution 4.0 License BY DOI: 10.19080/GJIDD.2021.07.555712

\section{Your next submission with Juniper Publishers} will reach you the below assets

- Quality Editorial service

- Swift Peer Review

- Reprints availability

- E-prints Service

- Manuscript Podcast for convenient understanding

- Global attainment for your research

- Manuscript accessibility in different formats

( Pdf, E-pub, Full Text, Audio)

- Unceasing customer service

Track the below URL for one-step submission https://juniperpublishers.com/online-submission.php 